\title{
FLUX-CORED WIRES \\ AT THE WORLD AND REGIONAL MARKETS OF WELDING CONSUMABLES (Review)
}

\author{
A.A. MAZUR, O.K. MAKOVETSKAYA, S.V. PUSTOVOJT and N.S. BROVCHENKO \\ E.O. Paton Electric Welding Institute, NASU \\ 11 Bozhenko Str., 03680, Kiev, Ukraine. E-mail: office@paton.kiev.ua
}

\begin{abstract}
Electric arc welding is one of the basic technologies of industrial economy. The industrialized countries are characterized by a sustainable development of welding production and appearance of new technologies, welding equipment, as well as new consumables at the market. The main factors of wide application of welding technologies and surfacing using flux-cored wire in various industries and construction are high quality of welds and efficiency of welding process. The article presents analysis of the world and regional markets of flux-cored wire. In the world a steady growth in using mechanized and automatic welding and surfacing using powder consumables is observed. To meet the rising demand for flux-cored wire at the separate regional markets in a number of countries, new production capacities for its production are created. For example, in China, where rates of development of welding production are far ahead not only the industrialized countries but also certain regions, over the past decade new facilities for production of powder welding and surfacing consumables were put into operation. The level of mechanization and automation of arc welding is increased both in separate countries as well as around the world in general. The production capacities of Ukrainian producers allow completely satisfying the demand for flux-cored wire at the domestic market. 15 Ref., 7 Tables, 7 Figures.
\end{abstract}

$\boldsymbol{K} \boldsymbol{e} \boldsymbol{y} \boldsymbol{w} \boldsymbol{o r d s}:$ welding, welding production, flux cored wire, technology, market, state-of-the-art, prospects

Electric arc welding is the basic technology of creating permanent joints of metals and non-metals in many fields of industry and construction. Therefore, improving its efficiency and quality is one of the main tasks in welding production. The breakthrough in improving electric arc welding processes was creation of technologies and equipment for mechanized and automatic welding and surfacing using flux-cored wires and strips, development of high-quality powder welding and surfacing consumables. Already more than 60 years the significant contribution to the development of new technologies and equipment for mechanized and automatic welding and surfacing, development of welding and surfacing consumables, as well as technologies and equipment for their production is made by the E.O. Paton Electric Welding Institute of the NAS of Ukraine.

World market. Despite a relatively high cost, flux-cored wires are ever more demanded at the world market of welding consumables. In view of wide application of welding technologies and surfacing using flux-cored wires and strips in the economically developed countries their consump- tion in industry and construction is growing every year, despite the short-term recessions during periods of crisis in the world economy. Thus, for example, during the financial crisis of 2008-2009 and the economic crisis caused by it, the market volume of welding consumables dropped by more than $30 \%$ (such tendency was observed at the market of flux-cored wire). However by 2011, the sales of welding consumables reached a precrisis level and in the subsequent years it exceeded it. According to the estimates of leading analytical companies such as BBC Research and Transparency Market Research, the cost volume of welding equipment market in 2013 exceeded 17 billion USD. According to the forecast of these companies the market volume will reach 2425 billion USD by 2020 , and its annual growth in the period of 2014-2020 is expected at 4.5$5.3 \%[1,2]$. Data on the dynamics of cost volume of the world market of welding equipment and its structure in 2010-2012 and forecast of development until 2017 [3] are shown in Figure 1. One of the basic segments of the market of welding technology is the market of welding consumables. In 2013, the cost volume of market of welding consumables reached 8.75 billion USD, which amounts more than a half of the world market. The structure and dynamics of develop- 


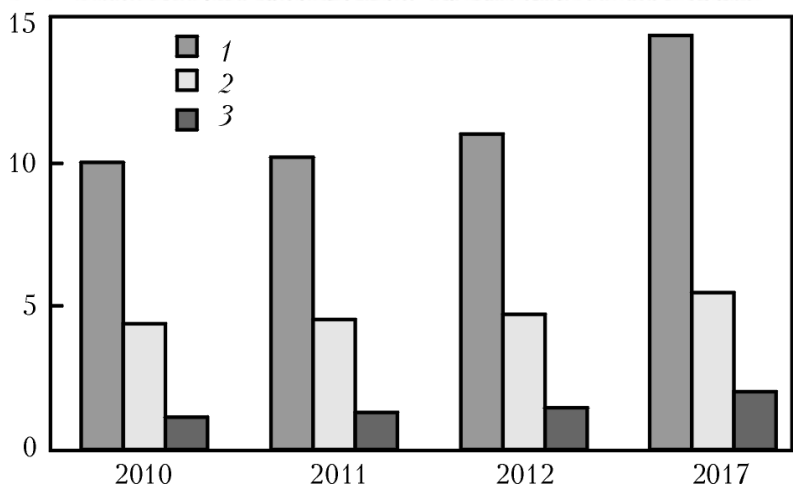

Figure 1. Dynamics of growth of the world welding market in 2010-2017, billion USD: 1 - welding consumables, shielding gas, protection means; 2 - welding equipment; 3 - automatic machines/robots, accessories

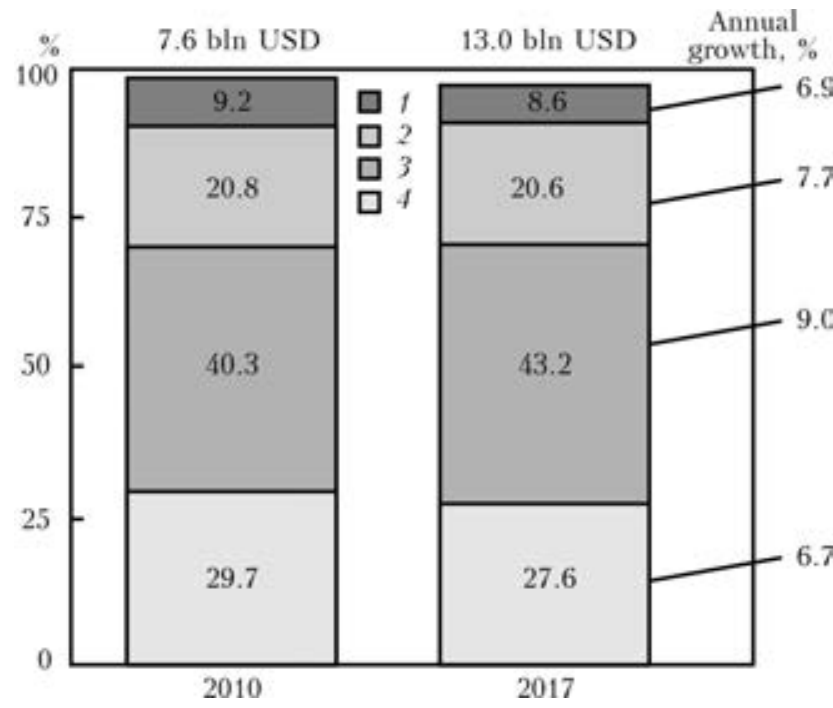

Figure 2. Structure and dynamics of development of the world market of welding consumables categorized by the main product segments (2017 - forecast): 1 - wire and flux (SAW); 2 - flux-cored wire; 3 - solid wire; 4 electrodes
Table 1. The world market of flux-cored wire in 2011-2013

\begin{tabular}{||c|c|c|c||}
\hline \multirow{2}{*}{ Year } & \multicolumn{3}{|c|}{ Market of welding consumables } \\
\cline { 2 - 4 } & $\begin{array}{c}\text { World, in total, } \\
\text { thou t }\end{array}$ & $\begin{array}{c}\text { Flux-cored wire, } \\
\text { thou t }\end{array}$ & $\begin{array}{c}\text { Share of } \\
\text { flux-cored wire, \% }\end{array}$ \\
\hline 2011 & 5945.6 & 748.7 & 12.5 \\
\hline 2012 & 6213.3 & 820.7 & 13.2 \\
\hline 2013 & 6283.6 & 863.7 & 13.8 \\
\hline
\end{tabular}

ment of the world market of welding consumables in 2010-2017 according to the estimates of Frost\&Sullivan [4] is shown in Figure 2.

In terms of cost values in the structure of the world market of welding consumables the fluxcored wire makes a little more than $20 \%$, but the rate of annual growth of its share is inferior only to a solid wire segment. The cost volume of the world market of flux-cored wire for welding and surfacing in 2010 amounted to 1.58 billion USD. In 2012 it amounted to 1.81 billion USD and by 2017 it will reach 2.56 billion USD [5].

In real terms, the world market of welding consumables according to The Japan Welding News for the World in 2013 exceeded 6.2 million tons, of which about $14 \%$ or 864,000 tons is flux-cored wire. Data on the flux-cored wire production in the world in 2011-2013 are shown in Table $1[6,7]$.

In the industrialized countries, in the structure of consumption of welding consumables the share of flux-cored wire amounts to the following values, \%: Korea - 40: Japan - 35.9; North America -22.1 ; EU - 19.1; Taiwan - 18.8.

The main sectors, where welding technologies using powder welding consumables are widely used are, first of all, shipbuilding and construction of offshore structures (platforms, berths,

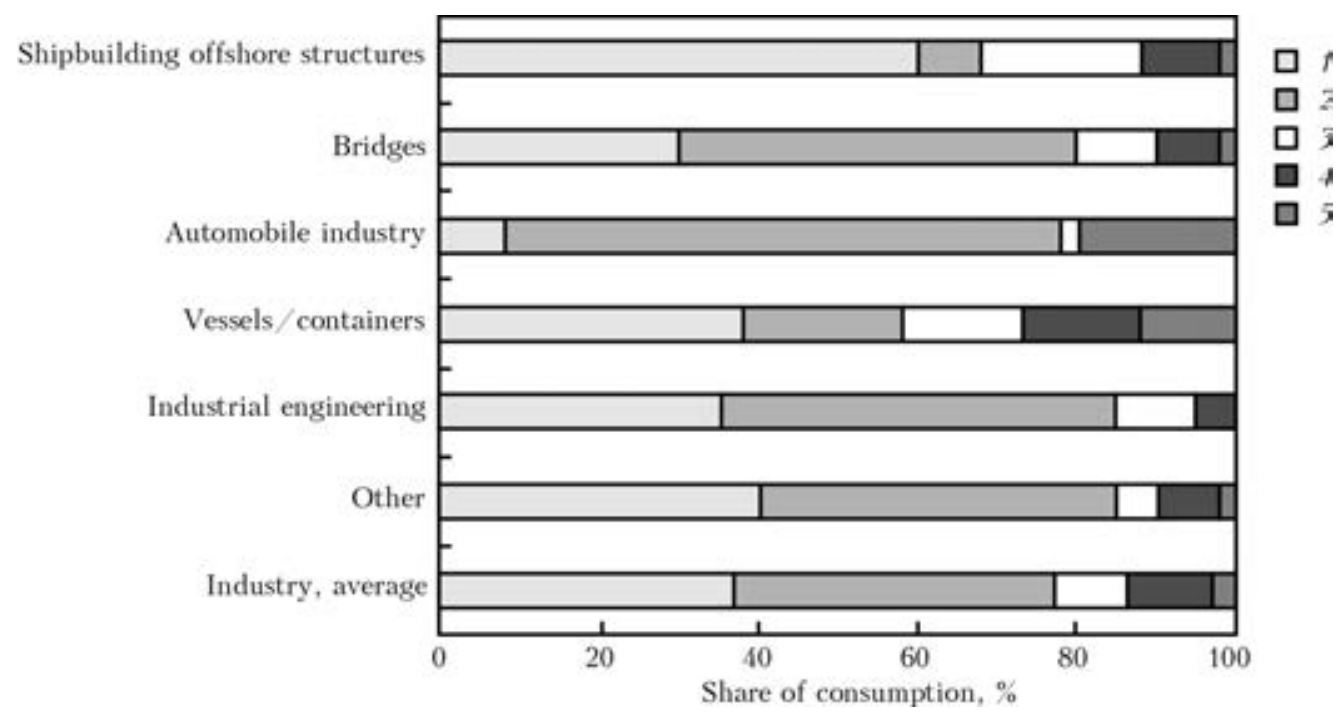

Figure 3. Share of the main types of welding consumables in different branches of industry in Japan: 1 - flux-cored wire; 2 - solid wire; 3 - electrodes; 4 - wire and flux (SAW) 


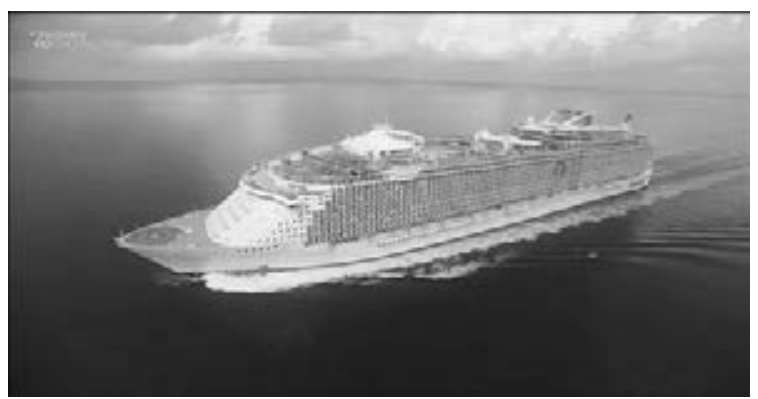

Figure 4. Cruise liner «Oasis of the Seas», 2009

etc.), bridge construction, manufacture of vessels and containers, industrial engineering, power engineering, construction of pipelines. The structure of consumption of the main types of welding consumables in different industries in Japan [8] is shown in Figure 3.

In shipbuilding and oil-and-gas sector the share of mechanized GMAW performed using flux cored-wire amounts almost to $80 \%$. Thus, for example, in Finland during construction of the largest cruise liner «Oasis of the Seas» the length of welds was $2400 \mathrm{~km}$. During construction of the ship more than $1000 \mathrm{~kg}$ of welding consumables was consumed. During assembly and welding of hull structures of the ship, $75 \%$ of welds are produced using flux-cored wire welding technologies, and relatively 15 and $9 \%$ using submerged arc and manual arc welding ( $\mathrm{Fi}-$ gure 4).

Flux-cored wire is widely used also in the construction of various architectural erections of steel building structures. Thus, during construction of the stadium Donbass Arena (Donetsk, Ukraine) the powder welding consumables were used for mechanized welding in shielding gases and submerged arc welding (Figure 5).

A new direction in application of welding consumables for mechanized welding in bridge construction is the refuse from solid wires and implementation of a new generation of metal fluxcored wires specially designed for steel bridge construction. This wire was used in the construction of a unique steel bridge of cable-beam system with an arched pylon across the Moscow River (Figure 6), the bridge across the Zolotoy Rog Bay in Vladivostok (RF), etc.

In the manufacture of offshore platforms and related equipment the seamless flux-cored wires of rutile type with a rapidly solidifying slag crust suitable for welding in all spatial positions were widely applied [9].

Currently, there is an intensive growing demand for welding and surfacing materials applied in the sector of repair and maintenance. Welding, soldering and surface strengthening (deposition), as well as thermal spraying (plasma, gas

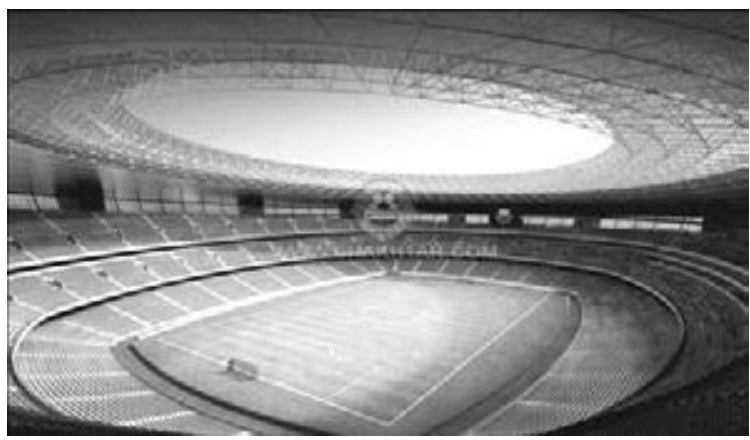

Figure 5. Stadium «Donbass Arena» (Donetsk), 2009

flame, high speed gas flame (HVOF) and arc). The cost volume of the world market of welding consumables for this sector makes about 2 billion USD and by 2017 its annual growth by $4.5 \%$ is expected. The structure of the market of welding consumables for repair and maintenance, according to the data of [10], for the flux-cored wire is $24 \%$, for electrodes is $50 \%$, for solid wire is $24 \%$ and for wire for submerged arc welding is $2 \%$.

Regional markets of flux-cored wire. The large segment of the world market of welding consumables is the Asian region. The market of Asian countries makes more than $70 \%$ of the world market of welding consumables and $68 \%$ of the world market of flux-cored wire. The market share of flux-cored wire in Europe and North America is $12 \%$ each. The data on volume and structure of consumption of the main types of welding consumables in a number of regions of the world are given in Table $2[6,7]$.

At present, China became the leader of the world and regional consumption of welding consumables and, respectively, flux-cored wire. The major share of consumption of welding consumables in China makes up nevertheless covered electrodes $(46 \%)$, but the consumption of fluxcored wire in industry is constantly growing. In 2013, the volume of consumption of flux-cored wire amounted to 330,000 tons or $38.2 \%$ of the world consumption and in the structure of con-

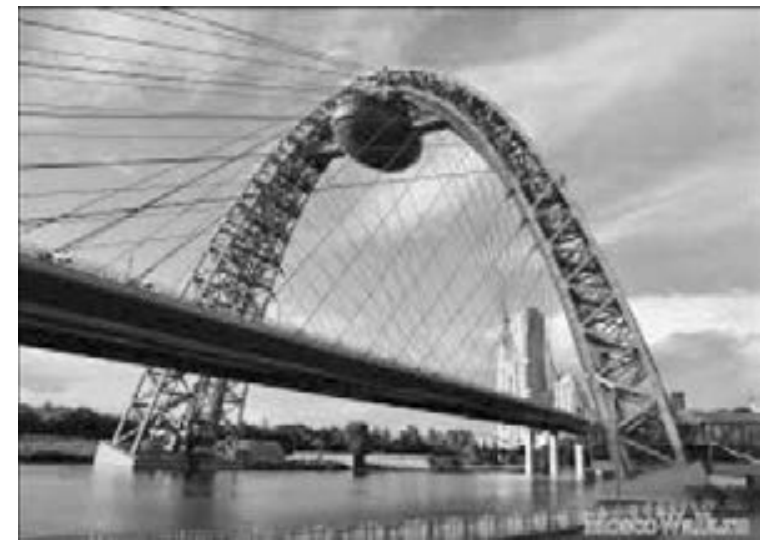

Figure 6. Bridge crossing in Serebryany Bor (Moscow) 
Table 2. Volume and structure of welding consumables consumption in different regions of the world in 2013

\begin{tabular}{|c|c|c|c|c|c|c|c|c|c|c|}
\hline \multirow[t]{2}{*}{ Region } & \multicolumn{2}{|c|}{ Electrodes } & \multicolumn{2}{|c|}{$\begin{array}{l}\text { Wire for SAW } \\
\text { and flux }\end{array}$} & \multicolumn{2}{|c|}{ Solid wire } & \multicolumn{2}{|c|}{ Flux-cored wire } & \multicolumn{2}{|c|}{ In total } \\
\hline & thou $\mathrm{t}$ & $\%$ & thou $\mathrm{t}$ & $\%$ & thou $\mathrm{t}$ & $\%$ & thou $\mathrm{t}$ & $\%$ & thou $\mathrm{t}$ & $\%$ \\
\hline Europe & 58.3 & 11 & 68.9 & 13 & 296.8 & 56 & 106.0 & 20 & 530 & 100 \\
\hline North America & 55.2 & 12 & 46.0 & 10 & 253.0 & 55 & 105.8 & 23 & 460 & 100 \\
\hline Central and South America & 103.4 & 47 & 19.8 & 9 & 79.2 & 36 & 17.6 & 8 & 220 & 100 \\
\hline Russia (the Customs Union) & 105.6 & 48 & 30.8 & 14 & 66.0 & 30 & 17.6 & 8 & 220 & 100 \\
\hline Asia & 1866.3 & 42 & 505.2 & 11 & 1508.5 & 34 & 583.6 & 13 & 4464.6 & 100 \\
\hline Middle East & 95.0 & 50 & 19.0 & 10 & 58.9 & 31 & 17.1 & 9 & 190 & 100 \\
\hline Africa & 82.5 & 55 & 12.0 & 8 & 43.5 & 29 & 12.0 & 8 & 150 & 100 \\
\hline Oceania & 23.0 & 46 & 4.5 & 9 & 18.5 & 37 & 4.0 & 8 & 50 & 100 \\
\hline World, in total & 2389.3 & 38 & 706.2 & 11 & 2324.4 & 37 & 863.7 & 14 & 6283.6 & 100 \\
\hline
\end{tabular}

sumption of welding consumables it had already amounted to $10 \%$.

Despite the growth of production capacities of flux-cored wire in China, a significant increase in its import volume should be noted. If by 2000 the import of flux-cored wire was not higher than $40 \%$ of the domestic production, since 2001 the volume of import of flux-cored wire began to exceed the volumes of its production and currently it amounts to almost $100 \%$ of the volume of flux-cored wire produced in the country.

Figure 7 shows data characterizing the share of consumption of flux-cored wire of the main regions and countries in the world consumption of flux-cored wire and share of consumption of flux-cored wire in the structure of domestic consumption of welding consumables.

China shot up to the leaders of the world production and consumption of flux-cored wire relatively not long ago. As early as in 2002 the volume of production of flux-cored wire in China did not exceed 18,000 tons and the consumption was 35,000 tons. Whereas at that time Japan

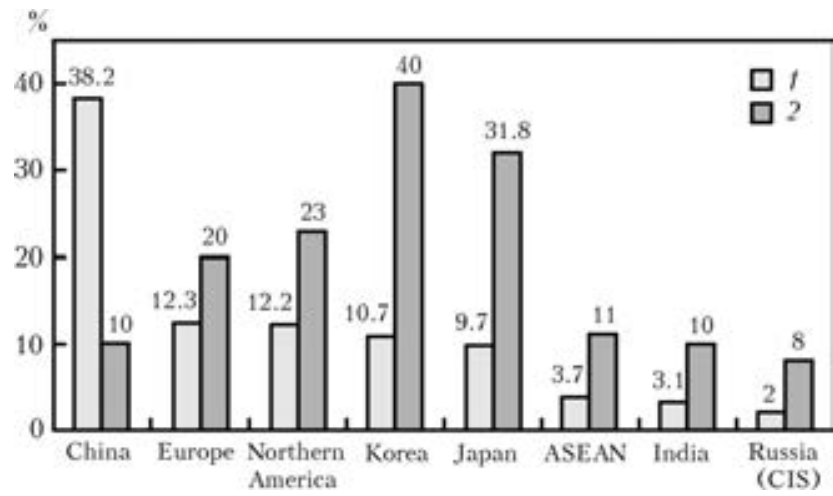

Figure 7. Share of flux-cored wire in the structure of consumption of regions and countries - the world major consumers of flux-cored wire, \%: 1 - in structure of the whole world consumption of flux-cored wire; 2 - in structure of domestic consumption of welding consumables produced already about 90,000 tons of flux-cored wire, of which 16,000 tons were exported. The total production of welding consumables in Japan in 2013 exceeded 280,000 tons and the consumption was 260,000 tons, of which $31.8 \%(83,000$ tons) is a flux-cored wire, $46.7 \%$ is a solid wire.

The recognized leader in production and consumption of flux-cored wire is the Republic of Korea. The country entered the world market of welding consumables relatively not long ago, but its market of welding consumables was developing very dynamically. Thus, over the ten year period from 1995 the quantitative volume of welding consumables in the country increased by 5 times and amounted to about 300,000 tons in 2005. Moreover the domestic consumption amounts to $62 \%$ of produced welding consumables, $38 \%$ of them are exported [11]. More than $70 \%$ of welding consumables produced in the country is the solid and flux-cored wire. The leading manufacturer of welding consumables in Korea - Hyundai Welding Co Ltd. - is among 15 companies the world leaders in production of welding consumables. Its share of sales on the domestic market of welding consumables amounts to $45 \%$.

The volume of the European market of welding consumables in terms of cost value amounts to about 2.1 billion euros and in the recent years tends to decrease. In 2013, the volume of consumption of welding consumables in the European countries amounted to about 530,000 tons, of which $20 \%$ makes flux-cored wire.

The main producers and consumers of welding consumables in Europe are Germany, France and Italy. The volumes of production of the main types of consumables for welding, brazing, thermal spraying in the EU countries are the follow- 
Table 3. Production of welding consumables in Germany in 2011-2013

\begin{tabular}{|c|c|c|c|c|}
\hline \multirow{2}{*}{ Welding and auxiliary materials } & \multicolumn{3}{|c|}{ Volume of production, mln euro } & \multirow{2}{*}{$\begin{array}{c}\text { Change } \\
2013 / 2012, \%\end{array}$} \\
\hline & 2011 & 2012 & 2013 & \\
\hline Welding wire and strip (excluding wire and strip with coating and filling) & 271.5 & 255.3 & 245.6 & -3.8 \\
\hline Covered electrodes for arc welding & 112.1 & 97.9 & 70.2 & -28.2 \\
\hline Flux-cored wire for arc welding & 53.1 & 53.3 & 52.3 & -1.9 \\
\hline Rods with coating for brazing and autogenous welding & 41.8 & 34.7 & 32.9 & -5.2 \\
\hline Auxiliary consumables for welding and brazing of metals & 144.4 & 148.9 & 149.6 & +0.4 \\
\hline In total & 622.9 & 590.1 & 550.7 & -6.7 \\
\hline
\end{tabular}

Table 4. Production of welding consumables in Germany in 2009-2011

\begin{tabular}{|c|c|c|c|c|}
\hline \multirow{2}{*}{ Welding and auxiliary materials } & \multicolumn{3}{|c|}{ Volume of production, thou $\mathrm{t}$} & \multirow{2}{*}{$\begin{array}{c}\text { Change } \\
2009 / 2008, \%\end{array}$} \\
\hline & 2011 & 2012 & 2013 & \\
\hline Welding wire and strip (excluding wire and strip with coating and filling) & 129.2 & 111.0 & 108.8 & -2.0 \\
\hline Covered electrodes for arc welding & 12.6 & 12.3 & 12.0 & -3.0 \\
\hline Flux-cored wire for arc welding & 23.4 & 21.7 & 20.7 & -5.0 \\
\hline Rods with coating for brazing and autogenous welding & 1.5 & 1.3 & 1.2 & -8.0 \\
\hline Auxiliary consumables for welding and brazing of metals & 46.0 & 53.5 & 50.9 & -5.0 \\
\hline In total & 212.7 & 199.7 & 193.6 & -3.0 \\
\hline
\end{tabular}

ing, million euros [12]: Germany - 549; France - 238; Italy - 193; UK - 137; the Netherlands - 73; Czech Republic - 7; others - 830; EU (27) - 2027.

Germany produces about one third of the total volume of production of welding consumables in the EU countries, whereas Germany, France and Italy together produce almost a half of output of all the consumables in the EU.

In the structure of production and application of welding consumables in the EU countries a solid wire (almost $56 \%$ ) is dominated and a flux-cored wire amounts to about $20 \%$.

The data of cost and quantitative volume of production of welding consumables in Germany on the separate product groups, which are presented in Tables 3 and 4, allow evaluating the volume and structure of production of consumables in Europe in 2011-2013. According to the data of these Tables, the volume of production of welding consumables in cost value was reduced almost by $7 \%$ in 2013 and in real terms - by $3 \%$. For the certain types of products, such as for example, covered electrodes, the reduction in cost value terms was $30 \%$ [10].

Basing on the data presented in Tables 3 and 4 and on the fact that Germany produces $30 \%$ of the entire European volume of production of welding consumables, the cost volume of production of welding consumables in the EU countries in 2013 amounted to almost 1.8 billion euros, and about 645,000 tons of welding consumables were produced.

Russia. The volume of production of welding consumables in Russia is constantly decreasing. Since 2001 their production decreased by 3 times, and in 2013 it amounted to about 120,000 tons, of which $80 \%$ were covered electrodes [13].

The volume of production of flux-cored wire is not high. In the best pre-crisis years (2007) it was about 5,000 tons at the total volume of production of welding consumables of 320,000 tons. Currently, according to the evaluation of producers of welded structures in Russia the industrial production of flux-cored wire is established mainly at the enterprise «InterPro» (Oryol region). The main reason for reduction of capacities is lack of quality raw materials and closing of enterprises [14].

Russia increases import of welding consumables, including flux-cored wire. The import of welding consumables in 2001-2014 increased by 5.4 times from 7.3 to 38.6 thou t, including fluxcored wire - by almost 3.6 times from 1.5 to 5.4 thou t. The main suppliers of flux-cored wire are the companies ESAB (China), Lincoln Electric (China), Hyundai (South Korea), Kobelco (Holland) [14].

The share of the CIS countries (including Russia) in the structure of the world market of welding consumables does not exceed $3.5 \%$. According to The Japan Welding News for the World, in 2013 the quantitative volume of market of 
INTERNATIONAL CONFERENCE «SURFACING»

Table 5. Volume of consumption of welding consumables in the world and CIS countries (including Russia) in 2013

\begin{tabular}{|c|c|c|c|c|}
\hline \multirow{2}{*}{ Welding consumables } & \multicolumn{2}{|c|}{ World } & \multicolumn{2}{|c|}{ CIS (including Russia) } \\
\hline & thou $t$ & $\%$ & thou $\mathrm{t}$ & $\%$ \\
\hline Covered electrodes & 2389.3 & 100 & 105.6 & 4.4 \\
\hline Flux-cored wire & 863.7 & 100 & $17.6^{* *}$ & 2.0 \\
\hline Wire for SAW & 706.2 & 100 & 30.8 & 4.4 \\
\hline Solid wire & 2324.4 & 100 & 66.0 & 2.8 \\
\hline In total & 6283.6 & 100 & $220^{*}$ & 3.5 \\
\hline
\end{tabular}

Table 6. Volume of consumption of welding consumables in CIS countries (including Russia) in 2011-2013.

\begin{tabular}{|c|c|c|c|c|c|c|}
\hline \multirow{2}{*}{ Welding consumables } & \multicolumn{2}{|c|}{2011} & \multicolumn{2}{|c|}{2012} & \multicolumn{2}{|c|}{2013} \\
\hline & thou $\mathrm{t}$ & $\%$ & thou $\mathrm{t}$ & $\%$ & thou $\mathrm{t}$ & $\%$ \\
\hline Covered electrodes & 112.2 & 51 & 112.7 & 49 & 105.6 & 48 \\
\hline Flux cored wire & 13.2 & 6 & 18.4 & 8 & 17.6 & 8 \\
\hline Wire for SAW & 30.8 & 14 & 32.2 & 14 & 30.8 & 14 \\
\hline Solid wire & 63.8 & 29 & 66.7 & 29 & 66.0 & 30 \\
\hline In total & 220 & 100 & 230 & 100 & 220 & 100 \\
\hline
\end{tabular}

welding consumables in the CIS countries (including Russia) amounted to 220,000 tons. In Tables 5 and 6 the data of volume and structure of consumption of welding consumables in the CIS countries in 2011-2013 are given [6, 7].
Within the framework of the program of import substitution being developed today in Russia the works on evaluation of the possibility of increasing domestic production of welding consumables began. However, if in respect of welding electrodes and solid wire the experts note a pos-

Table 7. Apparent consumption of welding and filler materials in Ukraine (according to the State Statistics Service of Ukraine), thou $\mathrm{t}$

\begin{tabular}{|c|c|c|c|c|c|c|}
\hline Description & In total & $\begin{array}{l}\text { Conventional } \\
\text { welding wire }\end{array}$ & $\begin{array}{l}\text { Alloyed welding } \\
\text { wire }\end{array}$ & Flux-cored wire & $\begin{array}{l}\text { Welding } \\
\text { electrodes }\end{array}$ & Welding fluxes \\
\hline & & \multicolumn{5}{|c|}{2011} \\
\hline Production & 86.7 & 8.7 & 11.5 & $0.2^{*}$ & 43.0 & 25.1 \\
\hline Export & 28.1 & - & 2.2 & 0.6 & 8.1 & 17.2 \\
\hline Import & 10.8 & - & 6.4 & 0.6 & 1.1 & 2.7 \\
\hline \multirow[t]{2}{*}{ Apparent consumption } & 69.4 & 8.7 & 15.7 & 0.2 & 36.0 & 10.6 \\
\hline & & \multicolumn{5}{|c|}{2012} \\
\hline Production & 78.2 & 7.7 & 10.0 & 0.2 & 38.6 & 21.7 \\
\hline Export & 25.6 & - & 2.3 & 0.6 & 7.0 & 15.7 \\
\hline Import & 10.2 & - & 7.0 & 0.5 & 1.2 & 1.5 \\
\hline \multirow[t]{2}{*}{ Apparent consumption } & 62.8 & 7.7 & 14.7 & 0.1 & 32.8 & 7.5 \\
\hline & & \multicolumn{5}{|c|}{2013} \\
\hline Production & 77.9 & 7.5 & 10.0 & 0.2 & 40.4 & 19.8 \\
\hline Export & 27.2 & - & 1.6 & 0.3 & 10.5 & 13.9 \\
\hline Import & 12.7 & - & 8.6 & 0.5 & 1.4 & 1.6 \\
\hline Apparent consumption & 63.4 & 7.5 & 17.0 & 0.4 & 31.3 & 7.5 \\
\hline
\end{tabular}


sibility of setting up the production of these types of welding consumables of the required quality, the increase in production of flux-cored wire remains an open question.

Ukraine. Ukraine economy is one of the mostly affected by the crisis in Europe. In the period of 2008-2009 the decline in industrial production exceeded $30 \%$. The general state of the economy was reflected in the volume of production and consumption of welding equipment, including welding consumables. The volume of their production decreased by $40 \%$ in the period of 2008-2009.

In the subsequent years, the volume of production of welding consumables began to recover, but the level of 2007 (111.4 thou t) was not reached. In 2013 the volume of production of welding consumables in Ukraine amounted to 80,000 tons, of which $40 \%$ were welding electrodes and $20 \%$ was flux. The production of flux-cored wire in Ukraine amounts to about $1500 \mathrm{t} /$ year. The volumes of export and import amount to about $600 \mathrm{t} /$ year. In Table 7 the data of the Ukrainian Statistics Committee and the E.O. Paton Electric Welding Institute are presented showing the volumes of production, consumption and trade of the main types of welding consumables in Ukraine in 2011-2013 [15].

The consumption of welding consumables in 2011-2013 years reduced by $28 \%$. The major share of import made a solid alloyed wire, and the major share of export made fused fluxes. It should be noted that despite the significant reduction in production and consumption of welding consumables, during already many years Ukraine has a positive trade balance of welding consumables.

\section{Conclusions}

Welding is the basic technology in many branches of industry and construction. The dynamics of the world production and consumption of structural materials allows making a prediction about increase in volume of the world welding production in the nearest future, despite a temporary crisis in economy of some countries and regions, the demand for welding consumables will grow.
The analysis of the world and regional markets of flux-cored wire showed that in the world a sustainable growth in application of mechanized and automatic welding with powder welding and surfacing materials and increase in their production are observed due to putting into operation of the new production capacities to meet the growing demand.

A high efficiency and quality of welds determine the wide application of welding and surfacing technologies using flux-cored wire in different branches of industry of economically developed and a number of developing countries.

The production capacities available in Ukraine allow completely satisfying the domestic needs in flux-cored wire.

1. (2010) Welding products market is set to reach USD 23.78 billion by 2010. http://www.transparencymarketresearch.com

2. (2013) Victor Technology Group, Inc.: Annual report 2013. http://www.victortechnologies.com

3. Welding equipment and supplies: The global market. http://www.bccresearch.com

4. Sudhakar Ruth Sudhakar. Key growtn accelerators for the global welding consumables market. http://www.frost.com

5. (2013) Multiple benefits to underpin appeal of fluxcored wires. Welding and Cutting, 5, 286.

6. (2014) General description for welding consumables. The Japan Welding News for the World, 67, 4-5.

7. (2012) General description for welding consumables market. Ibid., 59, 5-6.

8. Morimoto, T. (2005) Developments in flux-cored wire for gas-shielded arc welding. Kobelco Techn. Rev., 26, 49-53.

9. Rosert, R., Karasyov, M.V. (2012) Flux-cored wires: Tendencies, development and their industrial application. In: Proc. of Int. Sci.-Techn. Conf. on Welding Consumables (St.-Petersburg), 220-230.

10. Chauhan, A. Welding requirements for repairs and maintenance increased adoption of preventive maintenance leads the market for welding. http://www.frost.com

11. Cho Seon Mook (2005) State-of-the-art of welding materials and instrument in Korea. J. JWS, 74(1), 18-19.

12. (2014) Schweissen und Schneiden 2013 - Keingutes Jahr. Schweissen und Schneiden, 66(9), 500-513.

13. Sidlin, Z.A. (2009) Current status of welding consumables production in Russia. The Paton Welding J., 2, 23-25.

14. (2014) UNCOMTRAD. http://comtrade.un.org 15.

15. Economics review of welding production and market of welding equipment of Ukraine in 1990-2013. Kiev: PWI.

Received 13.05.2015 